\title{
Clinical heterogeneity of abnormal glucose homeostasis associated with the HNF4A R311H mutation
}

\author{
Maurizio Delvecchio ${ }^{1 *}$, Rosa Di Paola ${ }^{2}$, Davide Mangiacotti ${ }^{2}$, Michele Sacco $^{3}$, Claudia Menzaghi $^{2}$ \\ and Vincenzo Trischitta ${ }^{2,4}$
}

Keywords: Diabetes mellitus, HNF4A-MODY, Monogenic diabetes, Children, Adults, Gestational diabetes, Type 2 diabetes

\section{Correspondence \\ Dear Sir,}

Maturity Onset Diabetes of the Young (MODY; MIM\# 606391) represents a genetically and clinically heterogeneous form of diabetes mellitus (DM) [1-3], characterized by hyperglycaemia or overt diabetes, in at least two or three consecutive generations, onset $<25$ years of age, absence of anti ß-cells antibodies. Loss-of-function HNF4A mutations cause a progressive loss of $\beta$-cell function [4] and, eventually, frank hyperglycaemia denominated as MODY1. HNF4A mutations have been associated with MODY1, type 2 diabetes and gestational diabetes (GDM) [5].

\section{Findings}

We describe a 10 years old diabetic girl recruited within a sample of MODY patients [6], Personal history: she is the first of two children born from non-consanguineous parents and was born full term and appropriate for gestational age after a pregnancy complicated by GDM. No transient congenital hyperinsulinism was detected [7]. She was healthy until the age of 9.1 years, when she was admitted to the local Hospital because of fainting. At admission, the following was recorded: blood glucose of $200 \mathrm{mg} / \mathrm{dl}$; blood pressure, fundus oculi, heart ultrasound, electrocardiogram, blood biochemistry and $\mathrm{pH}$ were all normal; antithyroid and anti $\beta$-cells antibodies were negative; finally, oral glucose tolerance test (OGTT) was consistent with DM (Table 1), with reduced insulin production (Matsuda

\footnotetext{
* Correspondence: mdelvecchio75@gmail.com

"Dipartimento di Scienze e Chirurgia Pediatriche, U.O. "B Trambusti", A.O.U.

Consorziale Policlinico Giovanni XXIII, Bari 70100, Italy

Full list of author information is available at the end of the article
}

Index 17.18, HOMA-IR 0.98, Insulinogenic Index -0.02, Disposition Index 0). Familial history was as follows: 40 years old healthy father; 35 years old mother, diagnosed as having GDM in both pregnancies (during pregnancies fasting blood glucose ranging from 110 to $140 \mathrm{mg} / \mathrm{dl}$, blood glucose at 120' of OGTT $597 \mathrm{mg} / \mathrm{dl}$ and 403 during the first and the second pregnancy, respectively); a 6 years old healthy brother; maternal grandmother and one out of 2 maternal uncles with type 2 DM which was diagnosed when he was 30 years old.

At admission, two IU of regular insulin at lunch and at dinner and a hypocaloric diet (BMI $24.1 \mathrm{~kg} / \mathrm{m}^{2}$, 95th centile) were started. Three weeks later, body weight had dropped $1 \mathrm{~kg}$ and insulin injections were stopped because of recurrent hypoglycaemias. The patient was referred to our Unit 5 months later, still off of insulin. At that time, $\mathrm{HbA} 1 \mathrm{c}$ was $40 \mathrm{mmol} / \mathrm{mol}$ and BMI $19.4 \mathrm{~kg} / \mathrm{m} 2$ (75th centile). The HNF4A (NM_175914.4) gene analysis by PCR followed by direct sequencing showed the p.R311H c.932G > A variation in exon 8 (previously reported as p. $\mathrm{R} 323 \mathrm{H}[8]$ ). This mutation resides in the highly conserved extreme carboxy terminal domain [9] and causes a semiconservative aminoacid substitution predicted to be probably damaging by The Human Gene Mutation Database (http://www.hgmd.org) [10] and by PolyPhen-2 tool [11]. Genetic analysis was carried out also in first-degree relatives and in the maternal uncles, showing the same mutation in the mother, the brother, and the diabetic uncle. They underwent a comprehensive laboratory evaluation (Table 1). When 7.9 year-old, the brother underwent further examination showing impaired glucose tolerance (IGT) (baseline and after 120' blood glucose and insulin: 
Table 1 The table shows clinical and biochemistry data of the proband at DM diagnosis in the upper part and data at last examination of all mutation carriers (including proband) in the lower part

\begin{tabular}{|c|c|c|c|c|}
\hline \multicolumn{5}{|c|}{ Proband's data at the time of clinical diagnosis of DM (i.e. at age of 9.1 years) } \\
\hline \multicolumn{2}{|c|}{$\mathrm{HbA} 1 \mathrm{c}(\mathrm{mmol} / \mathrm{mol})$} & \multicolumn{3}{|c|}{58} \\
\hline \multicolumn{2}{|c|}{ C-peptide (ng/ml) } & \multicolumn{3}{|c|}{2.9} \\
\hline \multicolumn{2}{|c|}{ Total/HDL cholesterol (mg/dl) } & \multicolumn{3}{|c|}{$176 / 34$} \\
\hline \multicolumn{2}{|c|}{ Triglycerides (mg/dl) } & \multicolumn{3}{|c|}{105} \\
\hline \multicolumn{2}{|c|}{ Systolic/diastolic blood pressure $(\mathrm{mmHg})$} & \multicolumn{3}{|c|}{$113 / 65$} \\
\hline \multicolumn{2}{|c|}{ Fundus oculi } & \multicolumn{3}{|c|}{ Normal } \\
\hline \multicolumn{2}{|c|}{ Anti-thyroid, ICA, GAD, IA-2 antigens antibodies } & \multicolumn{3}{|c|}{ Negative } \\
\hline \multicolumn{2}{|c|}{ Oral glucose tolerance test } & Blood glucose (mg/dl) & \multicolumn{2}{|c|}{ Blood insulin (microU/ml) } \\
\hline \multicolumn{2}{|c|}{ Before glucose load } & 100 & \multicolumn{2}{|c|}{10.4} \\
\hline \multicolumn{2}{|c|}{30 min after glucose load } & 215 & \multicolumn{2}{|c|}{57.2} \\
\hline \multicolumn{2}{|c|}{$60 \mathrm{~min}$ after glucose load } & 308 & \multicolumn{2}{|c|}{82.2} \\
\hline \multicolumn{2}{|c|}{90 min after glucose load } & 351 & \multicolumn{2}{|c|}{84.3} \\
\hline \multicolumn{2}{|c|}{120 min after glucose load } & 320 & \multicolumn{2}{|c|}{77.7} \\
\hline Clinical data & Proband & Brother & Mother & Uncle \\
\hline Age at examination (yrs) & 10.7 & 8 & 36.5 & 33.1 \\
\hline Age at diagnosis (yrs) & 9.1 & 7.2 & 26 & 30.2 \\
\hline Glycaemic status diagnosed & Transient DM & IGT & GDM & DM \\
\hline Age at genetic testing (yrs) & 9.6 & 7.2 & 35.9 & 32.5 \\
\hline BMI $\left(\mathrm{Kg} / \mathrm{m}^{2}\right)$ & 19 & 19.5 & 20.9 & 26.3 \\
\hline Blood pressure $(\mathrm{mmHg})$ & $107 / 68$ & $110 / 60$ & $160 / 90$ & $130 / 80$ \\
\hline $\mathrm{HbA} 1 \mathrm{c}(\mathrm{mmol} / \mathrm{mol})$ & 6.1 & 37 & 40 & 60 \\
\hline Fasting blood glucose $(\mathrm{mg} / \mathrm{dl})$ & 99 & 72 & 80 & 171 \\
\hline C-peptide (ng/ml) & 1.9 & 1.3 & 1.1 & 1.4 \\
\hline Insulin (microU/ml) & 7.6 & 3.5 & 3 & 4.3 \\
\hline Total cholesterol (mg/dl) & 157 & 126 & 152 & 177 \\
\hline HDL cholesterol (mg/dl) & 57 & 35 & 55 & 50 \\
\hline LDL cholesterol (mg/dl) & 80 & 77 & 83.8 & 118 \\
\hline Triglycerides (mg/dl) & 59 & 54 & 66 & 45 \\
\hline Creatinine (mg/dl) & 0.45 & 0.59 & 0.67 & 0.89 \\
\hline Albuminuria (mg/dl) & 7 & 8.4 & 3 & 8.2 \\
\hline Glycosuria (mg/dl) & Absent & Absent & Absent & Absent \\
\hline Anti-hyperglycaemic therapy & None & None & Diet, physical activity & Diet, physical activity \\
\hline Fundus oculi & Normal & Normal & Normal & Normal \\
\hline
\end{tabular}

DM: diabetes mellitus. IGT: impaired glucose tolerance at OGTT. GDM: gestational diabetes mellitus.

78 and $151 \mathrm{mg} / \mathrm{dl}, 6.4$ and $58.7 \mathrm{ng} / \mathrm{ml}$, respectively), low insulin production (Matsuda Index 28.56, HOMA-IR 0.77, Insulinogenic Index -0.05 , Disposition Index 0), HbA1c $39 \mathrm{mmol} / \mathrm{mol}$, and BMI $20.4 \mathrm{~kg} / \mathrm{m}^{2}$ (90th centile).

\section{Conclusions}

HNF4A mutations lead to a progressive decrease of insulin secretion and hyperglycaemia [12] requiring oral hypoglycaemic drugs or insulin in most cases
[13]. Our proband required low insulin dose (0.09 IU/ $\mathrm{kg}$ /day) only for few weeks. This transient course is puzzling and never described in HNF4A-MODY children so far. Likely, in the weeks before the diagnosis, some triggering factors played a role in deteriorating glucose homeostasis. As she became normoglycaemic and insulin free after some weight lost, we suggest that overweight may have played a major role, but we cannot exclude the role of other concomitant factors (stress or 
infectious diseases). Currently the proband, 11-year-old, is on normocaloric diet and presents a good glycaemic control (HbAlc $40 \mathrm{mmol} / \mathrm{mol}$ ) without any hypoglycaemic treatment.

We did not perform any molecular study showing the effect of the mutation, so no direct effect can be postulated. However, we show that it segregates with hyperglycaemia, as it was found in the mother (GDM, currently normoglycaemic and normal weight), in the maternal uncle (type 2 $\mathrm{DM}$ onset at 30 years of age, currently overweight, diabetic and on hypoglycaemic diet), and in the brother (IGT). The same mutation was previously described in a 46 year-old obese man with type $2 \mathrm{DM}$ and nephropathy [8]. Later, in the same position, a mutation with Arginine replaced by Cysteine (previously reported as p.R324C), was described in a 13 year-old Japanese MODY patient [14]. Unfortunately, no information about the families were reported in both cases, making impossible to speculate about any role of HNF4A-R311H on glucose homeostasis. To better assess its pathogenic role, we screened 198 non-diabetic individuals and 138 type 2 DM patients without family history of autosomal dominant inheritance of hyperglycaemia / diabetes and negative data were obtained.

The in silico analysis suggests that the $\mathrm{R} 311 \mathrm{H}$ mutation causes a semiconservative aminoacid substitution predicted to be probably damaging $[10,11]$. Since some studies indicates a neutral [15], and others a deleterious [16] effect of such variation on HNF4A transcriptional activity, its biological role is controversial.

In conclusion, we report on a family with the HNF4A$\mathrm{R} 311 \mathrm{H}$ mutation cosegregating with heterogeneous phenotype of abnormal glucose homeostasis, including MODY1. The lack of a clear genotype-phenotype association requires great caution before considering this mutation causative of MODY1. We suggest that also transient DM warrants the screening for MODY in the presence of indicative family history, even if with clinical heterogeneity of abnormal glucose homeostasis.

\section{Consent}

Informed consent was obtained from the patient's parents for publication of this case report.

\section{Abbreviations \\ DM: Diabetes mellitus; IGT: Impaired glucose tolerance; OGTT: Oral glucose tolerance test; GDM: Gestational diabetes mellitus.}

\section{Competing interests}

The authors declare that they have no competing interests.

\section{Authors' contributions}

DM and RDP carried out the molecular genetic studies and participated in the sequence alignment. MD and VT participated in the clinical care and investigations of children and adults. MD and CM conceived the case report. $\mathrm{VT}, \mathrm{RDP}$, and MS coordinated and helped to draft the manuscript. MS and CM drafted the manuscript. All authors read and approved the final manuscript.

\section{Acknowledgements}

The study was partially supported by Italian Ministry of Health grant RC2013 to MS.

\section{Author details}

'Dipartimento di Scienze e Chirurgia Pediatriche, U.O. "B Trambusti", A.O.U. Consorziale Policlinico Giovanni XXIII, Bari 70100, Italy. ${ }^{2}$ Research Unit of Diabetes and Endocrine Diseases, IRCCS Casa Sollievo della Sofferenza, San Giovanni Rotondo (FG) 71013, Italy. ${ }^{3}$ Paediatrics Unit IRCCS Casa Sollievo della Sofferenza, San Giovanni Rotondo (FG) 71013, Italy. ${ }^{4}$ Department of Experimental Medicine, 'Sapienza' University, Rome 00161, Italy.

Received: 24 February 2014 Accepted: 12 June 2014

Published: 19 June 2014

\section{References}

1. Shields BM, Hicks S, Shepherd MH, Colclough K, Hattersley AT, Ellard S: Maturity-onset diabetes of the young (MODY): how many cases are we missing? Diabetologia 2012, 53:2504-2508.

2. Fajans SS, Bell Gl, Polonsky KS: Molecular mechanisms and clinical pathophysiology of maturity-onset diabetes of the young. N Engl J Med 2001, 345:971-980.

3. Schober E, Rami B, Grabert M, Thon A, Kapellen T, Reinehr T, Holl RW, DPVWiss Initiative of the German Working Group for Paediatric Diabetology: Phenotypical aspects of maturity-onset diabetes of the young (MODY diabetes) in comparison with Type 2 diabetes mellitus (T2DM) in children and adolescents: experience from a large multicentre database. Diabet Med 2009, 26:466-473.

4. Herman WH, Fajans SS, Smith MJ, Polonsky KS, Bell GI, Halter JB: Diminished insulin and glucagon secretory responses to arginine in nondiabetic subjects with a mutation in the hepatocyte nuclear factor-4alpha/ MODY1 gene. Diabetes 1997, 46(11):1749-1754.

5. Watanabe RM, Black MH, Xiang AH, Allayee H, Lawrence JM, Buchanan TA Genetics of gestational diabetes mellitus and type 2 diabetes. Diabetes Care 2007, 30(2):S134. 140. Review. Erratum in: Diabetes Care 2007, 30(12):3154

6. Delvecchio M, Ludovico O, Bellacchio E, Stallone R, Palladino T, Mastroianno S, Zelante L, Sacco M, Trischitta V, Carella M: MODY type 2 P59S GCK mutant: founder effect in South of Italy. Clin Genet 2013, 83:83-87.

7. Pearson ER, Boj SF, Steele AM, Barrett T, Stals K, Shield JP, Ellard S, Ferrer J, Hattersley AT: Macrosomia and hyperinsulinaemic hypoglycaemia in patients with heterozygous mutations in the HNF4A gene. PLoS Med 2007, 4(4):e118

8. Price JA, Fossey SC, Sale MM, Brewer CS, Freedman BI, Wuerth JP, Bowden DW: Analysis of the HNF4 alpha gene in Caucasian type II diabetic nephropathic patients. Diabetologia 2000, 43(3):364-372.

9. Ryffel GU: Mutations in the human genes encoding the transcription factors of the hepatocyte nuclearfactor (HNF)1 and HNF4 families: functional and pathological consequences. J Mol Endocrinol 2001, 27(1):11-29.

10. Stenson PD, Mort M, Ball EV, Shaw K, Phillips AD, Cooper DN: The human gene mutation database (HGMD $\left.{ }^{\circledR}\right): 2008$ update. Genome Med 2008, 1(1):13.

11. Adzhubei IA, Schmidt S, Peshkin L, Ramensky VE, Gerasimova A, Bork P, Kondrashov AS, Sunyaev SR: A method and server for predicting damaging missense mutations. Nat Methods 2010, 7(4):248-249.

12. Gupta RK, Vatamaniuk MZ, Lee CS, Flaschen RC, Fulmer JT, Matschinsky FM, Duncan SA, Kaestner KH: The MODY1 gene HNF-4alpha regulates selected genes involved in insulin secretion. J Clin Invest 2005, 115(4):1006-1015.

13. Pearson ER, Pruhova S, Tack CJ, Johansen A, Castleden HA, Lumb PJ, Wierzbicki AS, Clark PM, Lebl J, Pedersen O, Ellard S, Hansen T, Hattersley AT Molecular genetics and phenotypic characteristics of MODY caused by hepatocyte nuclear factor 4a mutations in a large European collection. Diabetologia 2005, 48:878-885.

14. Yorifuji T, Fujimaru R, Hosokawa Y, Tamagawa N, Shiozaki M, Aizu K, Jinno K, Maruo Y, Nagasaka H, Tajima T, Kobayashi K, Urakami T: Comprehensive molecular analysis of Japanese patients with pediatric-onset MODY-type diabetes mellitus. Pediatr Diabetes 2012, 13:26-32. 
15. Oxombre B, Moerman E, Eeckhoute J, Formstecher P, Laine B: Mutations in hepatocyte nuclear factor 4alpha (HNF4alpha) gene associated with diabetes result in greater loss of HNF4alpha function in pancreatic beta-cells than in nonpancreatic beta-cells and in reduced activation of the apolipoprotein CIII promoter in hepatic cells. J Mol Med (Berl) 2002, 80(7):423-430.

16. Chandra V, Huang P, Potluri N, Wu D, Kim Y, Rastinejad F: Multidomain integration in the structure of the HNF-4a nuclear receptor complex. Nature 2013, 495(7441):394-398.

doi:10.1186/1824-7288-40-58

Cite this article as: Delvecchio et al: Clinical heterogeneity of abnormal glucose homeostasis associated with the HNF4A R311H mutation. Italian Journal of Pediatrics 2014 40:58.

\section{Submit your next manuscript to BioMed Central and take full advantage of:}

- Convenient online submission

- Thorough peer review

- No space constraints or color figure charges

- Immediate publication on acceptance

- Inclusion in PubMed, CAS, Scopus and Google Scholar

- Research which is freely available for redistribution 